\title{
Extender osmolality, glycerol and egg yolk on the cryopreservation of epididymal spermatozoa for gamete banking of the Cantabric Chamois (Rupicapra pyrenaica parva)
}

\author{
Felipe Martínez-Pastor ${ }^{\mathrm{a}, \mathrm{b}, *}$, Mercedes Álvarez ${ }^{\mathrm{b}, \mathrm{c}}$, Camino Guerra $^{\mathrm{c}}$, César A. Chamorro ${ }^{\mathrm{b}, \mathrm{c}}$, Luis Anel-López ${ }^{\mathrm{b}, \mathrm{c}}$, \\ Paulino de Paz ${ }^{\mathrm{a}, \mathrm{b}}$, Luis Anel ${ }^{\mathrm{b}, \mathrm{c}}$, Manuel Álvarez-Rodriguez ${ }^{\mathrm{b}, \mathrm{d}, \mathrm{e}}$ \\ ${ }^{a}$ Department of Molecular Biology (Cell Biology), Universidad de León, Spain \\ ${ }^{\mathrm{b}}$ INDEGSAL, Universidad de León, 24071, León, Spain \\ c Department of Medicine, Surgery and Veterinary Anatomy, Universidad de León, León, Spain \\ ${ }^{d}$ Department of Animal Health and Anatomy, Veterinary Faculty, Universitat Autònoma de Barcelona, Barcelona, Spain \\ ${ }^{\mathrm{e}}$ Department of Clinical and Experimental Medicine (IKE), BKH, Obstetrics and Gynecology, Linköping University, Linköping, Sweden
}

\section{A R T I C L E I N F O}

Article history:

Received 28 July 2018

Received in revised form 8 October 2018

Accepted 26 October 2018

Available online xxx

Keywords:

Cantabrian chamois

Cryopreservation

Epididymal spermatozoa

Extender

Osmolality

Glycerol

\begin{abstract}
A B S T R A C T
Germplasm banking is a key technology enabling the ex-situ conservation of wild species. However, cryopreservation protocols must be tested to assure the applicability of the banked material. The objective of this study was defining a range of parameters for the composition of a semen extender for Cantabrian chamois epididymal spermatozoa (post-mortem collection). The freezing extender was based in a TES-Tris-fructose buffer, modifying its composition in three experiments: Osmolality of the buffer $(320,380$ or $430 \mathrm{mOsm} /$ $\mathrm{kg}, 8 \%$ glycerol, $15 \%$ egg yolk), glycerol (4 or $8 \%, 430 \mathrm{mOsm} / \mathrm{kg}, 15 \%$ egg yolk), egg yolk (10 or $15 \%$, $430 \mathrm{mOsm} / \mathrm{kg}, 4 \%$ glycerol). Sperm was extended at $100 \mathrm{mill}$. spermatozoa $/ \mathrm{ml}$, cooled at $5^{\circ} \mathrm{C}$ and frozen at $-20^{\circ} \mathrm{C} / \mathrm{min}$. Sperm quality was assessed pre and post-thawing (CASA, HOS test, abnormal forms, cytoplasmic droplets, and viability and acrosomal damage by flow cytometry). Freezability was good overall, with total motility of $65.5 \% \pm 2.4$ initial and $55.8 \% \pm 2.4$ post-thawing. The extenders affected the post-thaw sperm quality marginally. Whereas osmolalities and glycerol concentrations seemed not to differ, $430 \mathrm{mOsm} / \mathrm{kg}$ and $4 \%$ glycerol might be preferred. Egg yolk concentrations only differed on sperm velocity (VCL: $84.0 \pm 6.7 \mu \mathrm{m} /$ $\mathrm{s}$ in $10 \%$ vs. $70.7 \pm 6.2 \mu \mathrm{m} / \mathrm{s}$ in $15 \%, P<0.05$ ). Our results suggest a good cryotolerance of chamois epididymal spermatozoa, with a preferred extender composition of hyperosmotic buffer, glycerol in the $4 \%$ range and lower egg yolk ( $10 \%$ range) than other ruminants.
\end{abstract}

(C) 2018

\section{Introduction}

Germplasm banking is crucial for the conservation of many wild species. Whereas we should aim at in situ preservation, preserved gametes, embryos or tissues allow for flexibility and long-term planning of conservation strategies. Moreover, germplasm banking allows for the increase of the genetic variability when the number of living individuals is low or populations are fragmented [1,2]. Moreover, this technology, together with artificial reproductive techniques (ART), is of interest for the maintenance of wild populations.

Few studies have dealt with chamois (Rupicapra sp.) spermatology or gamete banking technologies [3]. Whereas the two chamois species ( $R$. pyrenaica and $R$. rupicapra) are in the Least Concern status of the IUCN Red List of Threatened Species, many of its subspecies are listed as Vulnerable (R. p. ornata and R. r. cartusiana) or Critically Endangered (R. r. tatrica). Moreover, small populations of

\footnotetext{
* Corresponding author. INDEGSAL, University of León, Campus de Vegazana, 24071, León, Spain.

Email address: felipe.martinez@unileon.es (F. Martínez-Pastor)
}

the Least Concern subspecies are threatened by human activities and especially parasitic or viral diseases [4,5].

Our group characterized the male genitalia and epididymal spermatozoa in the subspecies $R$. p. parva (Cantabrian chamois), harvested from 99 hunted males in breeding (October-November) and non-breeding (June-September) periods [6]. We found high sperm counts and quality in most samples. Even in the non-breeding season, half of the samples were of acceptable quality. In another experiment, we found a good post-thawing quality using a Tris-citric acid-fructose extender, even in samples collected several days post-mortem (total motility $67.5 \% \pm 9.5$ for samples collected before $24 \mathrm{~h}$ ) [7]. Thus, these results were promising for setting up gamete banks from sperm samples collected from hunted animals. There is also a limited characterization for the Abruzzi chamois ( $R$. p . ornata), using only three animals captured and submitted to electroejaculation [8]. Whereas the semen quality was very poor in the non-breeding season, it was deemed acceptable in the breeding season, however achieving a limited amount of spermatozoa.

Another report on chamois sperm freezing was carried out with samples obtained by trans-rectal ultrasonic-guided massage of the ac- 
cessory sex glands (TUMASG) in the breeding season from six $R . p$. parva [9]. Sperm collection was on average lower than $10^{9}$ spermatozoa, but with average motility of fresh sperm of $83 \%$. In this study on cryopreservation of sperm in chamois, sperm extended in Tris-citric acid-glucose medium (TCG) and equilibrated for $3 \mathrm{~h}$ produced significantly better post thaw motility (47\%) than sperm equilibrated for $15 \min (40 \%)$.

Whereas these results could be acceptable for establishing a gamete bank for this species, it is important to achieve a high post-thawing quality in order to assure the viability and usefulness of the bank for future use [10]. The choice of the extender is a factor likely influencing the outcome of spermatozoa cryopreservation, and it might be affected by the source of the spermatozoa, as tested in ram [11]. Studies in red deer have shown different results for extenders with different osmolality $(320,380,430 \mathrm{mOsm} / \mathrm{kg})$ and glycerol concentration $(4 \%$ and $8 \%$ ), in electroejaculated and epididymal spermatozoa [12]. Thus, epididymal spermatozoa performed better in extenders with higher osmolality and glycerol, possibly mimicking the environmentspermatozoa are embedded in the epididymis. Contrarily, electroejaculated semen yielded better quality in lower osmolality and glycerol. However, differences for glycerol formulations were marginal [12]. The efficiency of high osmolalities around $400 \mathrm{mOsm} / \mathrm{kg}$ for freezing epididymal spermatozoa was confirmed in a subsequent study, together with the suitability of fructose as the sugar of choice for extender supplementation [13]. In another study [14], 20\% clarified egg yolk and $6 \%$ glycerol in combination with a rapid cooling rate yielded better post-thawing results (around 60\% motility) in epididymal spermatozoa than 3\% glycerol, non-clarified or other egg yolk proportions.

Therefore, our hypothesis is that varying components of the cryopreservation extender might increase the post-thawing quality of the epididymal spermatozoa obtained from chamois. Our objective is to optimized the cryopreservation extender, which would improve the future viability of sperm banks for this species. Thus, in this study, we describe the testing of several extenders, with several extender osmolalities and glycerol and egg yolk concentrations, in order to define some extender conditions that might lead subsequent studies to define an optimized cryopreservation protocol for this species.

\section{Materials and methods}

\subsection{Experimental design}

Several extenders were tested in three experiments, aimed at analysing the effect of the osmolality of the extender buffer, the glycerol concentration and the proportion of egg yolk. In each experiment, spermatozoa obtained from each male was split according to the number of extenders, extended and frozen. After one year, the doses were thawed and analysed.

In a first trial, spermatozoa from 14 males were extended and frozen in an extender with an osmolality of the base buffer of 320, 380 or $430 \mathrm{mOsm} / \mathrm{kg}$ (E320, E380 and E430). This base buffer was made of TES $231.1 \mathrm{mM}$ and Tris $77.1 \mathrm{mM}$, adding fructose to adjust the osmolality to each case: $16.9 \mathrm{mM}$ for $320 \mathrm{mOsm} / \mathrm{kg}, 74.7 \mathrm{mM}$ for 380 $\mathrm{mOsm} / \mathrm{kg}$ and $121.9 \mathrm{mM}$ for $430 \mathrm{mOsm} / \mathrm{kg}$. The $\mathrm{pH}$ was adjusted to 7.2. Glycerol was added up to $8 \%$ and egg yolk to $15 \%$.

In the second experiment, glycerol was added to the $430 \mathrm{mOsm} / \mathrm{kg}$ buffer with $15 \%$ egg yolk up to $4 \%$ or $8 \%$ (G4 and G8). Spermatozoa from 13 males were extended and frozen with these two extenders.
In a third trial, egg yolk was tested at $10 \%$ and $15 \%$ (EY10 and EY15) in the $430 \mathrm{mOsm} / \mathrm{kg}$ extender with $4 \%$ glycerol. Eleven males were included in this trial.

\subsection{Spermatozoa recovery, reagents and media}

Genitalia were collected from Cantabrian chamois ( $R$. pyrenaica parva) harvested during the breeding season (October and November) in the hunting reserves of Ancares, Mampodres and Picos de Europa (León, Spain). Animal age (estimated by the gamekeepers) was 3-10 years $(7.3 \pm 2.9 \mathrm{SD})$. Thus, animals were young adults to adults. The gamekeepers collected the genital of the harvested animals and took the samples to the researchers, who did not have direct contact width the animals in any case. Testes were refrigerated after extraction and processed within $24 \mathrm{~h}$. Epididymides preparation for sperm extraction was performed at $5^{\circ} \mathrm{C}$ [15]. Briefly, the cauda epididymides were exposed and cleaned, puncturing superficial blood vessels to remove as much blood as possible. The spermatozoa were collected by performing several cuts with a clean scalpel blade and gently collecting the sperm mass oozing out. The sperm mass from both epididymides was pooled and promptly evaluated and extended.

Reagents were purchased from Sigma-Aldrich (The Netherlands). Flow cytometry consumables were purchased from Becton Dickinson (Franklin Lakes, NJ). The media was prepared in our laboratory as described in each section.

\subsection{Sperm cryopreservation}

Prior to freezing, sperm quality was assessed after diluting a 5- $\mu$ l drop of sperm mass in $500 \mu \mathrm{l}$ of PBS and warming it at $37^{\circ} \mathrm{C}$ for $20 \mathrm{~min}$. Samples with total motility $\geq 30 \%$ total motility were used in the study (number of samples accepted for cryopreservation as displayed in section 2.1).

The epididymal sperm was extended with the same volume of the corresponding extender (see Experimental design) at $5^{\circ} \mathrm{C}$. After $2 \mathrm{~h}$ at $5^{\circ} \mathrm{C}$, we assessed the sperm concentration (Bürker haemocytometer), adjusting it at $100 \times 10^{6} \mathrm{ml}^{-1}$ and packing in $0.25 \mathrm{~mL}$ straws. The straws were frozen in a Planner MRII (Planner PLC, Middlesex, UK) programmable biofreezer at $-20^{\circ} \mathrm{C} / \mathrm{min}$ down to $-100^{\circ} \mathrm{C}$, and stored in liquid nitrogen. For analyses, the doses were thawed in a water bath at $65^{\circ} \mathrm{C}$ for $6 \mathrm{~s}$ and kept at $25^{\circ} \mathrm{C}$ for $10 \mathrm{~min}$.

\subsection{Sperm motility}

Samples were diluted down to $\sim 20 \times 10^{6} \mathrm{ml}^{-1}$ in PBS. A 5- $\mu \mathrm{L}$ drop in a Makler chamber $(10 \mu \mathrm{m}$ depth) was examined with a phase contrast microscope (Nikon Labophot-2; negative contrast optics), on a warming stage at $37^{\circ} \mathrm{C}$. The CASA system was a Motility Analyzer v. 7.4G (Hamilton-Thorne Research, Beverly, USA). At least 5 fields and 200 cells were recorded at $\times 200$, at 25 frames $/ \mathrm{s}$ in $0.8 \mathrm{~s}$, collecting the parameters: Total motility (MOT), progressive motility (PROG, VAP $>25 \mu \mathrm{m} / \mathrm{s}$ and STR $>80 \%$ ), VCL (curvilinear path velocity), VSL (straight path velocity), VAP (average path velocity according to the average — smoothed - path; $\mu \mathrm{m} / \mathrm{s}$ ), LIN (linearity), STR (straightness), WOB (wobble), ALH (amplitude of the lateral displacement of the sperm head), and BCF (frequency of the flagellar beat). Motility limit was set to $\mathrm{VCL}>10 \mu \mathrm{m} / \mathrm{s}$. 


\subsection{Abnormal forms and HOS test}

We determined the percentage of abnormal spermatozoa by fixing $5 \mu \mathrm{L}$ of sample in $500 \mu \mathrm{L}$ of buffered $2 \%$ glutaraldehyde. At least 200 spermatozoa were assessed at $\times 400$ phase contrast.

For assessing the functional integrity of the sperm plasma membrane, we performed a hypoosmotic swelling test (HOS test). Five $\mu \mathrm{L}$ of sample were incubated in $500 \mu \mathrm{L}$ of sodium citrate solution at 100 $\mathrm{mOsm} / \mathrm{kg}$ at room temperature, fixing after $18 \mathrm{~min}$ with a drop of $37 \%$ glutaraldehyde. The percentage of positive cells (those with a swollen flagella) was assessed as described above.

\subsection{Sperm viability and acrosomal damage}

Sperm samples were diluted $1 / 100$ in PBS with $25 \mu \mathrm{g} / \mathrm{ml}$ propidium iodide (PI) and $1 \mu \mathrm{g} / \mathrm{ml}$ peanut agglutinin (PNA) conjugated with FITC. After $10 \mathrm{~min}$ at $37^{\circ} \mathrm{C}$, the tubes were read (10000 events discarding debris) with a FACSCalibur flow cytometer (Becton Dickinson). Fluorochromes were excited with a $488 \mathrm{~nm}$ argon-laser a $650 \mathrm{LP}$ filter for detecting the red emission light of PI (650 long pass filter), and a 530/30 BP filter for the green emission light of FITC. We used the proportion of viable spermatozoa $\left(\mathrm{PI}^{-}\right)$, the proportion of damaged acrosomes $\left(\mathrm{PNA}^{+}\right)$and the proportion of damaged acrosomes in the viable population $\left(\mathrm{PNA}^{+}{ }_{\text {viab}}\right)$.

Table 1

Initial and for post-thaw CASA parameters for chamois sperm frozen in extenders with varying osmolality (Experiment 1, 4\% glycerol 15\% egg yolk: 320, 380 and $430 \mathrm{mOsm} /$ $\mathrm{kg}$ ). The last column shows the $P$ value for each analysis.

\begin{tabular}{llllll}
\hline & Initial & E320 & E380 & E430 & $P$ \\
\hline MOT $(\%)$ & $68.7 \pm 3.4$ & $69.5 \pm 4.3$ & $69.3 \pm 4.2$ & $71.2 \pm 4.1$ & 0.896 \\
PROG $(\%)$ & $24.6 \pm 5.0$ & $31.1 \pm 4.3$ & $29.1 \pm 4.6$ & $30.2 \pm 4.7$ & 0.139 \\
VAP $(\mu \mathrm{m} / \mathrm{s})$ & $75.0 \pm 4.6$ & $75.7 \pm 3.4$ & $76.3 \pm 3.3$ & $72.4 \pm 4.1$ & 0.765 \\
VCL $(\mu \mathrm{m} / \mathrm{s})$ & $111.0 \pm 9.7$ & $105.1 \pm 5.4$ & $104.7 \pm 7.0$ & $103.3 \pm 7.3$ & 0.861 \\
VSL $(\mu \mathrm{m} / \mathrm{s})$ & $49.4 \pm 4.1$ & $54.0 \pm 4.2$ & $53.7 \pm 3.9$ & $51.8 \pm 4.4$ & 0.706 \\
LIN $(\%)$ & $39.9 \pm 5.7$ & $51.6 \pm 3.6$ & $51.9 \pm 3.7$ & $47.3 \pm 4.9$ & 0.097 \\
STR $(\%)$ & $65.6 \pm 4.0$ & $68.4 \pm 3.7$ & $67.9 \pm 3.7$ & $67.6 \pm 4.1$ & 0.764 \\
WOB $(\%)$ & $70.6 \pm 2.6$ & $72.4 \pm 2.2$ & $74.1 \pm 2.0$ & $71.1 \pm 2.8$ & 0.454 \\
ALH $(\mu \mathrm{m})$ & $4.3 \pm 0.2$ & $4.9 \pm 0.3$ & $4.8 \pm 0.3$ & $4.7 \pm 0.3$ & 0.223 \\
BCF $(\mathrm{Hz})$ & $11.6 \pm 0.6$ & $10.6 \pm 0.7$ & $10.1 \pm 0.9$ & $10.3 \pm 0.8$ & 0.061 \\
\hline
\end{tabular}

MOT: Total motility; PROG: progressive motility; VAP: Average-path velocity (VAP; $\mu \mathrm{m} / \mathrm{s}$ ); VSL: straight-line velocity; VCL: Curvilinear velocity; LIN: Linearity; STR: Straightness; WOB: Wobble; ALH: Amplitude of the lateral movement of the head; BCF: Beat-cross frequency.

Different superscripts indicate that columns differ $\mathrm{P}<0.05$.

\subsection{Statistical analysis}

The R statistical package was used for data analysis, using linear mixed-effects models. The extenders were included as fixed effects and the male as the grouping factor in the random part of the model. Pairwise comparisons were adjusted by Holm's. Results are presented as means $\pm \mathrm{SEM}$, and the threshold for significance was set at $P<0.05$.

\section{Results}

In experiment 1 , post-thaw results (Tables 1 and 2 ) were not significantly different for the three extenders (E320, E380 and E480). In the case of HOS test, cytoplasmic droplets (distal and total) and $\mathrm{ACR}^{+}{ }_{\text {viab }}$, results were significantly lower post-thawing. Contrarily, midpiece defects and total abnormal forms were higher post-thawing. Since no differences were found between extenders, E430 was kept as the standard buffer in subsequent experiments, following our results with deer epididymal spermatozoa [12].

In the second experiment (Tables 3 and 4), there were no significant differences between glycerol concentrations, and G4 was selected for the third experiment because of the lower proportion of glycerol and the non-significant differences for viability and acrosomal damage.

In the third experiment, sperm velocities VCL and VAP (Table 5) were significantly higher for EY10 than for EY15. Considering morphology and viability parameters (Table 6), both yolk concentrations yielded similar results.

\section{Discussion}

Our study shows that acceptable quality can be achieved after cryopreservation of epididymal spermatozoa collected from chamois epididymides post-mortem. Apart from a recent report by our group on the effects of post-mortem time on chamois sperm quality and cryopreservation [7] and a pilot study with limited numbers [9], this is the first comprehensive study on the cryopreservation of chamois sperm testing the effect of various osmolalities, and glycerol and egg yolk concentrations. In our report [7], we used a TCF extender (430 mOsm/ $\mathrm{kg}, 15 \%$ egg yolk, $8 \%$ glycerol). Interestingly, we found a good resilience of chamois epididymal spermatozoa to refrigerated storage, allowing to obtain post-thawing quality up to 6 days post-mortem. This could in part explain that we only detected small differ-

Table 2

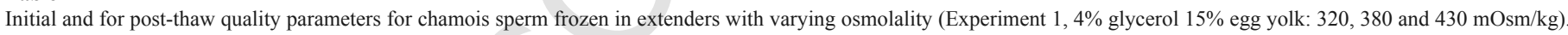
The last column shows the $P$ value for each analysis.

\begin{tabular}{|c|c|c|c|c|c|}
\hline & Initial & E320 & E380 & $\mathrm{E} 430$ & $P$ \\
\hline HOST $(\%)$ & $68.2 \pm 3.4^{\mathrm{a}}$ & $52.0 \pm 2.2^{\mathrm{b}}$ & $52.8 \pm 2.0^{\mathrm{b}}$ & $52.6 \pm 2.0^{\mathrm{b}}$ & $<0.001$ \\
\hline Abnormal, head (\%) & $10.5 \pm 1.4$ & $11.2 \pm 0.8$ & $11.5 \pm 0.7$ & $12.8 \pm 0.8$ & 0.204 \\
\hline Abnormal, midpiece (\%) & $3.0 \pm 0.8^{\mathrm{a}}$ & $5.6 \pm 0.5^{\mathrm{b}}$ & $5.8 \pm 0.3^{\mathrm{b}}$ & $7.2 \pm 0.6^{\mathrm{b}}$ & $<0.001$ \\
\hline Abnormal, tail (\%) & $8.3 \pm 2.7$ & $7.5 \pm 0.5$ & $7.1 \pm 0.6$ & $7.3 \pm 0.4$ & 0.876 \\
\hline Abnormal, total (\%) & $21.7 \pm 1.7^{\mathrm{a}}$ & $24.3 \pm 1.3^{\mathrm{ab}}$ & $24.3 \pm 1.3^{\mathrm{ab}}$ & $27.3 \pm 1.3^{\mathrm{b}}$ & 0.032 \\
\hline $\mathrm{CD}$, proximal (\%) & $2.2 \pm 0.8$ & $1.7 \pm 0.7$ & $1.4 \pm 0.5$ & $1.2 \pm 0.7$ & 0.370 \\
\hline $\mathrm{CD}$, distal $(\%)$ & $80.9 \pm 6.4^{\mathrm{a}}$ & $70.0 \pm 2.9^{\mathrm{b}}$ & $67.5 \pm 2.5^{\mathrm{b}}$ & $67.0 \pm 2.1^{\mathrm{b}}$ & 0.002 \\
\hline $\mathrm{CD}$, total $(\%)$ & $83.1 \pm 6.0^{\mathrm{a}}$ & $71.6 \pm 2.7^{\mathrm{b}}$ & $68.9 \pm 2.3^{\mathrm{b}}$ & $68.2 \pm 1.7^{\mathrm{b}}$ & $<0.001$ \\
\hline Viability (\%) & $66.3 \pm 3.7$ & $61.9 \pm 3.0$ & $64.3 \pm 3.0$ & $62.8 \pm 2.8$ & 0.586 \\
\hline DA $(\%)$ & $16.5 \pm 3.6$ & $21.6 \pm 2.0$ & $21.4 \pm 1.3$ & $22.2 \pm 1.8$ & 0.068 \\
\hline DA within viables $(\%)$ & $4.9 \pm 2.8^{\mathrm{a}}$ & $0.2 \pm 0.2^{\mathrm{b}}$ & $0.5 \pm 0.2^{\mathrm{ab}}$ & $0.2 \pm 0.2^{\mathrm{b}}$ & 0.046 \\
\hline
\end{tabular}

CD: Cytoplasmic droplets; DA: Damaged acrosomes.

Different superscripts indicate that columns differ $\mathrm{P}<0.05$. 
Table 3

Initial and for post-thaw CASA parameters for chamois sperm frozen in extenders with $4 \%$ or $8 \%$ glycerol (Experiment $2,430 \mathrm{mOsm} / \mathrm{kg} 15 \%$ egg yolk). The last column shows the $P$ value for each analysis.

\begin{tabular}{lllll}
\hline & Initial & G4 & G8 & $P$ \\
\hline MOT $(\%)$ & $67.4 \pm 4.1^{\mathrm{a}}$ & $50.6 \pm 7.9^{\mathrm{b}}$ & $49.7 \pm 8.0^{\mathrm{b}}$ & 0.016 \\
PROG $(\%)$ & $16.7 \pm 3.2^{\mathrm{a}}$ & $15.1 \pm 3.8^{\mathrm{b}}$ & $16.4 \pm 3.8$ & 0.689 \\
VAP $(\mu \mathrm{m} / \mathrm{s})$ & $76.1 \pm 3.8^{\mathrm{a}}$ & $59.8 \pm 5.5^{\mathrm{b}}$ & $61.9 \pm 5.1^{\mathrm{b}}$ & $<0.001$ \\
VCL $(\mu \mathrm{m} / \mathrm{s})$ & $119.6 \pm 8.9^{\mathrm{a}}$ & $82.2 \pm 10.6^{\mathrm{b}}$ & $84.8 \pm 10.2^{\mathrm{b}}$ & $<0.001$ \\
VSL $(\mu \mathrm{m} / \mathrm{s})$ & $43.5 \pm 2.4$ & $37.8 \pm 4.0$ & $39.2 \pm 4.0$ & 0.088 \\
LIN $(\%)$ & $38.2 \pm 2.9$ & $46.1 \pm 4.8$ & $45.5 \pm 4.5$ & 0.433 \\
STR $(\%)$ & $57.1 \pm 2.9^{\mathrm{a}}$ & $63.0 \pm 3.2^{\mathrm{b}}$ & $62.8 \pm 3.2^{\mathrm{b}}$ & 0.047 \\
WOB $(\%)$ & $66.6 \pm 1.9^{\mathrm{a}}$ & $76.6 \pm 2.4^{\mathrm{b}}$ & $75.6 \pm 2.3^{\mathrm{b}}$ & $<0.001$ \\
ALH $(\mu \mathrm{m})$ & $4.1 \pm 0.1^{\mathrm{a}}$ & $3.3 \pm 0.3^{\mathrm{b}}$ & $3.3 \pm 0.4^{\mathrm{b}}$ & 0.014 \\
BCF $(\mathrm{Hz})$ & $11.2 \pm 0.6^{\mathrm{a}}$ & $8.4 \pm 1.3^{\mathrm{b}}$ & $8.2 \pm 1.0^{\mathrm{b}}$ & $<0.001$ \\
\hline
\end{tabular}

MOT: Total motility; PROG: progressive motility; VAP: Average-path velocity (VAP; $\mu \mathrm{m} / \mathrm{s})$; VSL: straight-line velocity; VCL: Curvilinear velocity; LIN: Linearity; STR: Straightness; WOB: Wobble; ALH: Amplitude of the lateral movement of the head; BCF: Beat-cross frequency.

Different superscripts indicate that columns differ $\mathrm{P}<0.05$.

\section{Table 4}

Initial and for post-thaw quality parameters for chamois sperm frozen in extenders with $4 \%$ or $8 \%$ glycerol (Experiment $2,430 \mathrm{mOsm} / \mathrm{kg} 15 \%$ egg yolk). The last column shows the $P$ value for each analysis.

\begin{tabular}{lllll}
\hline & Initial & G4 & G8 & $P$ \\
\hline HOST (\%) & $66.1 \pm 4.0^{\mathrm{a}}$ & $50.5 \pm 2.4^{\mathrm{b}}$ & $49.3 \pm 3.4^{\mathrm{b}}$ & $<0.001$ \\
Abnormal, head (\%) & $19.2 \pm 3.3^{\mathrm{a}}$ & $13.2 \pm 0.7^{\mathrm{b}}$ & $13.7 \pm 0.5^{\mathrm{ab}}$ & 0.040 \\
Abnormal, midpiece (\%) & $3.2 \pm 0.6^{\mathrm{a}}$ & $5.5 \pm 0.7^{\mathrm{b}}$ & $5.9 \pm 0.5^{\mathrm{b}}$ & 0.012 \\
Abnormal, tail (\%) & $22.9 \pm 3.0^{\mathrm{a}}$ & $7.5 \pm 0.7^{\mathrm{b}}$ & $8.6 \pm 1.0^{\mathrm{b}}$ & $<0.001$ \\
Abnormal, total (\%) & $45.4 \pm 2.4^{\mathrm{a}}$ & $26.2 \pm 1.2^{\mathrm{b}}$ & $28.3 \pm 1.3^{\mathrm{b}}$ & $<0.001$ \\
CD, proximal (\%) & $14.4 \pm 2.7^{\mathrm{a}}$ & $5.9 \pm 1.7^{\mathrm{b}}$ & $3.5 \pm 1.0^{\mathrm{b}}$ & $<0.001$ \\
CD, distal (\%) & $67.0 \pm 5.4$ & $53.5 \pm 7.6$ & $54.6 \pm 6.8$ & 0.089 \\
CD, total (\%) & $81.4 \pm 3.1^{\mathrm{a}}$ & $58.9 \pm 6.7^{\mathrm{b}}$ & $58.1 \pm 6.5^{\mathrm{b}}$ & $<0.001$ \\
Viability (\%) & $69.1 \pm 3.0^{\mathrm{a}}$ & $53.6 \pm 3.8^{\mathrm{b}}$ & $50.7 \pm 4.0^{\mathrm{b}}$ & $<0.001$ \\
DA (\%) & $21.6 \pm 2.5$ & $25.0 \pm 2.9$ & $29.7 \pm 2.9$ & 0.058 \\
DA within viables (\%) & $2.4 \pm 0.5^{\mathrm{a}}$ & $0.9 \pm 0.5^{\mathrm{b}}$ & $0.1 \pm 0.1^{\mathrm{b}}$ & $<0.001$ \\
\hline
\end{tabular}

CD: Cytoplasmic droplets; DA: Damaged acrosomes.

Different superscripts indicate that columns differ $\mathrm{P}<0.05$.

Table 5

Initial and for post-thaw CASA parameters for chamois sperm frozen in extenders with $10 \%$ or $15 \%$ egg yolk (Experiment 3, $430 \mathrm{mOsm} / \mathrm{kg} 4 \%$ glycerol). The last column shows the $P$ value for each analysis.

\begin{tabular}{lllll}
\hline & Initial & EY10 & EY15 & $P$ \\
\hline MOT $(\%)$ & $65.0 \pm 4.5^{\mathrm{a}}$ & $51.6 \pm 8.6^{\mathrm{ab}}$ & $46.2 \pm 8.5^{\mathrm{b}}$ & 0.029 \\
PROG $(\%)$ & $18.9 \pm 3.4^{\mathrm{a}}$ & $21.6 \pm 5.0$ & $15.5 \pm 4.3$ & 0.304 \\
VAP $(\mu \mathrm{m} / \mathrm{s})$ & $71.5 \pm 2.1^{\mathrm{a}}$ & $63.1 \pm 4.8^{\mathrm{b}}$ & $54.2 \pm 3.8^{\mathrm{c}}$ & 0.003 \\
VCL $(\mu \mathrm{m} / \mathrm{s})$ & $107.9 \pm 4.7^{\mathrm{a}}$ & $84.0 \pm 6.7^{\mathrm{b}}$ & $70.7 \pm 6.2^{\mathrm{c}}$ & $<0.001$ \\
VSL $(\mu \mathrm{m} / \mathrm{s})$ & $42.5 \pm 2.7$ & $39.1 \pm 5.1$ & $36.5 \pm 3.1$ & 0.502 \\
LIN $(\%)$ & $40.2 \pm 3.0$ & $49.0 \pm 4.7$ & $49.3 \pm 4.9$ & 0.428 \\
STR $(\%)$ & $58.5 \pm 3.2$ & $63.6 \pm 6.0$ & $66.3 \pm 2.0$ & 0.370 \\
WOB $(\%)$ & $68.6 \pm 1.5^{\mathrm{a}}$ & $75.6 \pm 1.0^{\mathrm{b}}$ & $78.9 \pm 2.0^{\mathrm{b}}$ & $<0.001$ \\
ALH $(\mu \mathrm{m})$ & $4.0 \pm 0.2$ & $4.1 \pm 0.4$ & $3.4 \pm 0.4$ & 0.058 \\
BCF $(\mathrm{Hz})$ & $10.6 \pm 0.3^{\mathrm{a}}$ & $8.6 \pm 0.7^{\mathrm{b}}$ & $7.1 \pm 0.8^{\mathrm{b}}$ & $<0.001$ \\
\hline
\end{tabular}

MOT: Total motility; PROG: progressive motility; VAP: Average-path velocity (VAP; $\mu \mathrm{m} / \mathrm{s})$; VSL: straight-line velocity; VCL: Curvilinear velocity; LIN: Linearity; STR: Straightness; WOB: Wobble; ALH: Amplitude of the lateral movement of the head; BCF: Beat-cross frequency.

Different superscripts indicate that columns differ $\mathrm{P}<0.05$.

ences between extenders, since chamois epididymal spermatozoa could withstand stressing conditions successfully.

In the case of the study by Pradiee et al. [9], chamois semen $(\mathrm{n}=6)$ was frozen using a $345 \mathrm{mOsm} / \mathrm{kg}$ Tris-citric acid-glucose-based medium (TCG) with $6 \%$ egg yolk and $5 \%$ glycerol, concluding
Table 6

Initial and for post-thaw quality parameters for chamois sperm frozen in extenders with $10 \%$ or $15 \%$ egg yolk (Experiment 2, $430 \mathrm{mOsm} / \mathrm{kg} 4 \%$ glycerol). The last column shows the $P$ value for each analysis.

\begin{tabular}{lllll}
\hline & Initial & EY10 & EY15 & $P$ \\
\hline HOST (\%) & $67.4 \pm 4.7^{\mathrm{a}}$ & $49.9 \pm 4.2^{\mathrm{b}}$ & $51.5 \pm 2.7^{\mathrm{b}}$ & 0.002 \\
Abnormal, head (\%) & $19.2 \pm 3.3^{\mathrm{a}}$ & $12.6 \pm 0.7^{\mathrm{b}}$ & $13.2 \pm 0.7^{\mathrm{b}}$ & 0.028 \\
Abnormal, midpiece (\%) & $3.2 \pm 0.6^{\mathrm{a}}$ & $6.2 \pm 0.6^{\mathrm{b}}$ & $5.5 \pm 0.7^{\mathrm{b}}$ & 0.007 \\
Abnormal, tail (\%) & $22.9 \pm 3.0^{\mathrm{a}}$ & $9.5 \pm 1.0^{\mathrm{b}}$ & $7.5 \pm 0.7^{\mathrm{b}}$ & $<0.001$ \\
Abnormal, total (\%) & $45.4 \pm 2.4^{\mathrm{a}}$ & $28.4 \pm 1.3^{\mathrm{b}}$ & $26.2 \pm 1.2^{\mathrm{b}}$ & $<0.001$ \\
CD, proximal (\%) & $14.4 \pm 2.7^{\mathrm{a}}$ & $4.3 \pm 1.4^{\mathrm{b}}$ & $5.9 \pm 1.7^{\mathrm{b}}$ & $<0.001$ \\
CD, distal (\%) & $67.0 \pm 5.4$ & $54.4 \pm 7.2$ & $53.5 \pm 7.6$ & 0.084 \\
CD, total (\%) & $81.4 \pm 3.1^{\mathrm{a}}$ & $58.6 \pm 6.6^{\mathrm{b}}$ & $58.9 \pm 6.7^{\mathrm{b}}$ & $<0.001$ \\
Viability (\%) & $68.4 \pm 3.3^{\mathrm{a}}$ & $54.9 \pm 4.5^{\mathrm{b}}$ & $56.2 \pm 4.0^{\mathrm{b}}$ & $<0.001$ \\
DA (\%) & $24.3 \pm 1.9$ & $27.2 \pm 2.3$ & $25.2 \pm 3.4$ & 0.574 \\
DA within viables (\%) & $2.9 \pm 0.5^{\mathrm{a}}$ & $0.5 \pm 0.2^{\mathrm{b}}$ & $1.0 \pm 0.6^{\mathrm{b}}$ & 0.004 \\
\hline
\end{tabular}

CD: Cytoplasmic droplets; DA: Damaged acrosomes.

Different superscripts indicate that columns differ $\mathrm{P}<0.05$

that a longer one equilibration time ( $3 \mathrm{~h}$ vs. $15 \mathrm{~min}$ ) was advantageous not only for chamois but also for other ruminants like the ibex, mouflon and aoudad or Barbary sheep. Noticeably, these authors found that chamois was the most resilient species to shortening the equilibration time. This agrees with our results, given that we found only small differences between extenders. Nevertheless, we must be careful comparing our results with that study, since these authors used semen obtained by trans-rectal ultrasonic-guided massage of the accessory sex glands (TUMASG) [16]. Semen obtained by non-physiological means presents very different characteristics, specifically epididymal spermatozoa as they do not come into contact with the seminal plasma. Even with higher initial sperm quality, post thaw motility was lower in this proceeding study (e.g., total motility $47.5 \%$ ) compared to our results $(55.8 \%$ in pooled data). This is noteworthy, considering that testis and subsequent sperm recovery took sometimes place many hours after the animal's death, negatively affecting sperm characteristics [17,18]. Moreover, spermatozoa are quiescent in the epididymal medium and motility often develops during extension and freezing-thawing [19], an explanation for the good post-thawing motility found in Experiment 1.

We found similar results between the three osmolalities tested for freezing chamois epididymal spermatozoa, suggesting a strong resilience to osmotic changes. In previous studies in different species $[12,13,20,21]$, we have found that a hyperosmotic buffer is advantageous for freezing epididymal spermatozoa (ias it si similar to the hyperosmotic environment of the epididymis [22]). In the case of the red deer [12], we found a lower motility in the $320 \mathrm{mOsm} / \mathrm{kg}$ extender ( $42 \%-50 \%$ in the hyperosmotic extenders), but no differences in the other parameters. We found similar results in ram epididymal spermatozoa [21], with a slight improvement for $430 \mathrm{mOsm} / \mathrm{kg}$. Other authors reported on using $345 \mathrm{mOsm} / \mathrm{kg}$ extender for successfully freezing Spanish ibex epididymal spermatozoa [23], and an isotonic extender showed good results with goat epididymal spermatozoa [24]. Thus, epididymal spermatozoa from small ruminants could be cryopreserved in a wide range of osmolalities. Moreover, the post-mortem time might have greater influence on extender performance [21].

Similarly, the two glycerol concentrations yielded similar results, but we chose $4 \%$ mainly due to practical reasons: lower risk of toxicity and glycerol use. The choice of cryoprotectant and its proportion in the cryopreservation media is critical in relation to the intrinsic osmotic and toxic effects on the cells. Epididymal spermatozoa from red deer seemed to be tolerant to a wide range of glycerol, with similar performance of 4 and $8 \%$ but with a slight advantage for the latter 
[12], following the same pattern for ram [11]. These authors argued that epididymal spermatozoa could be more resilient to the toxic effects of glycerol than those ejaculated ones, therefore benefiting from its cryoprotective effects at larger concentrations. Moreover, $3 \%$ glycerol concentration achieved worse performance than $6 \%$ in red deer [25]. Studies reporting successful cryopreservation of epididymal spermatozoa from goat or ibex, phylogenetically closer to the chamois, used $5 \%[23,26]$ or $7 \%$ glycerol [24], supporting the hypothesis that epididymal spermatozoa from these species could be successfully cryopreserved in extenders regardless of their glycerol concentration.

Chamois epididymal spermatozoa were also marginally affected by egg yolk concentration, although $10 \%$ preserved motility better. Previous studies evidenced some differences between caprinae spermatozoa and other small ruminant groups on the egg yolk proportion for freezing epididymal spermatozoa. Thus, red deer and ram epididymal spermatozoa achieved higher quality in $20 \%$ egg yolk over lower concentrations $[11,14,25]$. Contrarily, $6 \%$ egg yolk seemed to achieve a higher in vitro fertility than $20 \%$ when freezing epididymal spermatozoa from the Spanish ibex (C. pyrenaica) [27]. However, results in this study were confounded by the fact that the buffers were different (Tris-citric acid-glucose - TCG — vs. Triladyl), and indeed $20 \%$ egg yolk showed higher post-thawing quality. Moreover, goat epididymal spermatozoa [24] were successfully frozen with $20 \%$ egg yolk, although the authors only used a single extender. Chamois semen obtained by TUMASG also achieved acceptable results freezing with $6 \%$ egg yolk, which agree with our results for a lower egg yolk concentration.

To sum up, we have tested different TTF-based cryopreservation extenders for freezing chamois epididymal spermatozoa, obtaining overall good post-thawing quality in all experiments. Our main conclusion is that chamois epididymal spermatozoa seem to be very resilient to changing conditions. However, our results suggest that the $430 \mathrm{mOsm} / \mathrm{kg}$ extender containing $4 \%$ glycerol and $10 \%$ egg yolk is most suitable.

\section{Conflicts of interest}

The authors have not declared any conflicts of interest.

\section{Acknowledgments}

The authors thank Juan José Martínez, César Gómez, Juan Carlos Peral, the Territorial Service of Environmental Affairs of León, and the gamekeepers of the hunting reserves of Picos de Europa, Mampodre and Ancares (León, Spain) for their collaboration in the collection of the samples. F. Martinez-Pastor was supported by a PhD grant (Ministry of Education, Culture and Sports, Spain) and by the Ramón y Cajal program (Spanish Ministry of Science and Innovation).

M. Álvarez-Rodriguez was supported by the Juan de la Cierva program (IJCI-2015-24380, MICINN, Spain).

\section{References}

[1] J.J. Garde, F. Martinez-Pastor, M. Gomendio, A.F. Malo, A.J. Soler, M. Fernandez-Santos, et al., The application of reproductive technologies to natural populations of red deer, Reprod Domest Anim 41 (Suppl 2) (2006) 93-102.

[2] J.G. Martínez, J. Carranza, J.L. Fernández-García, C.B. Sánchez-Prieto, Genetic variation of red deer populations under hunting exploitation in Southwestern Spain, J Wildl Manag 66 (2002) 1273-1282, https://doi.org/10.2307/3802960.

[3] L. Anel, P. De Paz, F. Martinez-Pastor, Rebeco (Rupicapra pyrenaica Bonaparte, 1845), in: J. Santiago-Moreno, A. López-Sebastián (Eds.), Ungulados Silv. Esp. Biol. Tecnol. Reprod. Para Su Conserv. Aprovech. Cinegético, Ministerio de Ciencia e Innovación. Instituto Nacional de Investigación y Tecnología Agraria y Alimentaria, Madrid, España, 2010, pp. 103-122.
[4] I. Marco, J.R. Lopez-Olvera, R. Rosell, E. Vidal, A. Hurtado, R. Juste, et al., Severe outbreak of disease in the southern chamois (Rupicapra pyrenaica) associated with border disease virus infection, Vet Microbiol 120 (2007) 33-41, https: //doi.org/10.1016/j.vetmic.2006.10.007.

[5] I. Marco, R. Rosell, O. Cabezón, G. Mentaberre, E. Casas, R. Velarde, et al., Epidemiological study of border disease virus infection in Southern chamois (Rupicapra pyrenaica) after an outbreak of disease in the Pyrenees (NE Spain), Vet Microbiol 127 (2008) 29-38, https://doi.org/10.1016/j.vetmic.2007.08.015.

[6] F. Martinez-Pastor, C. Guerra, M. Kaabi, V. Garcia-Macias, P. de Paz, M. Alvarez, et al., Season effect on genitalia and epididymal sperm from Iberian red deer, roe deer and Cantabrian chamois, Theriogenology 63 (2005) 1857-1875.

[7] M. Álvarez-Rodriguez, M. Álvarez, L. Anel-López, C. Guerra, C.A. Chamorro, L. Anel, et al., Effect of length of time post-mortem on quality and freezing capacity of Cantabric chamois (Rupicapra pyrenaica parva) epididymal spermatozoa, Anim Reprod Sci 198 (2018) 184-192, https://doi.org/10.1016/j.anireprosci. 2018.09.018.

[8] A. Carluccio, P. Ponzio, U. Tosi, I. De Amicis, D. Robbe, M. Pennelli, et al., Semen evaluation in the chamois of Abruzzi (Rupicapra pyrenaica ornata), Anim Reprod Sci 97 (2007) 186-190, https://doi.org/10.1016/j.anireprosci.2006.02. 005 .

[9] J. Pradiee, E. O'Brien, M.C. Esteso, C. Castaño, A. Toledano-Díaz, A. Lopez-Sebastián, et al., Effect of shortening the prefreezing equilibration time with glycerol on the quality of chamois (Rupicapra pyrenaica), ibex (Capra pyrenaica), mouflon (Ovis musimon) and aoudad (Ammotragus lervia) ejaculates, Anim Reprod Sci 171 (2016) 121-128, https://doi.org/10.1016/j.anireprosci.2016.06.007.

[10] S.M.H. Andrabi, W.M.C. Maxwell, A review on reproductive biotechnologies for conservation of endangered mammalian species, Anim Reprod Sci 99 (2007) 223-243, https://doi.org/10.1016/j.anireprosci.2006.07.002.

[11] M. Álvarez, J. Tamayo-Canul, C. Martínez-Rodríguez, E. López-Urueña, S. Gomes-Alves, L. Anel, et al., Specificity of the extender used for freezing ram sperm depends of the spermatozoa source (ejaculate, electroejaculate or epididymis), Anim Reprod Sci 132 (2012) 145-154, https://doi.org/10.1016/j. anireprosci.2012.05.006.

[12] F. Martínez-Pastor, F. Martínez, V. García-Macías, M.C. Esteso, E. Anel, M.R. Fernández-Santos, et al., A pilot study on post-thawing quality of Iberian red deer spermatozoa (epididymal and electroejaculated) depending on glycerol concentration and extender osmolality, Theriogenology 66 (2006) 1165-1172, https: //doi.org/10.1016/j.theriogenology.2006.03.027.

[13] M.R. Fernández-Santos, F. Martínez-Pastor, V. García-Macías, M.C. Esteso, A.J. Soler, P. de Paz, et al., Extender osmolality and sugar supplementation exert a complex effect on the cryopreservation of Iberian red deer (Cervus elaphus hispanicus) epididymal spermatozoa, Theriogenology 67 (2007) 738-753, https:// doi.org/10.1016/j.theriogenology.2006.10.005.

[14] M.R. Fernández-Santos, M.C. Esteso, A.J. Soler, V. Montoro, J.J. Garde, Effects of egg yolk and cooling rate on the survival of refrigerated red deer (Cervus elaphus hispanicus) epididymal spermatozoa, Reprod Domest Anim 41 (2006) 114-118, https://doi.org/10.1111/j.1439-0531.2006.00649.x.

[15] F. Martinez-Pastor, V. Garcia-Macias, M. Alvarez, C. Chamorro, P. Herraez, P. de Paz, et al., Comparison of two methods for obtaining spermatozoa from the cauda epididymis of Iberian red deer, Theriogenology 65 (2006) 471-485.

[16] S. Abril-Sánchez, A. Freitas-de-Melo, F. Beracochea, J.P. Damián, J. Giriboni, J. Santiago-Moreno, et al., Sperm collection by transrectal ultrasound-guided massage of the accessory sex glands is less stressful than electroejaculation without altering sperm characteristics in conscious goat bucks, Theriogenology 98 (2017) 82-87, https://doi.org/10.1016/j.theriogenology.2017.05.006.

[17] M. Kaabi, P. Paz, M. Alvarez, E. Anel, J.C. Boixo, H. Rouissi, et al., Effect of epididymis handling conditions on the quality of ram spermatozoa recovered post-mortem, Theriogenology 60 (2003) 1249-1259.

[18] J. Santiago-Moreno, A. Toledano-Díaz, A. Pulido-Pastor, A. Gómez-Brunet, A López-Sebastián, Birth of live Spanish ibex (Capra pyrenaica hispanica) derived from artificial insemination with epididymal spermatozoa retrieved after death, Theriogenology 66 (2006) 283-291, https://doi.org/10.1016/j.theriogenology. 2005.11.012.

[19] F. Martinez-Pastor, V. Garcia-Macias, M. Alvarez, P. Herraez, L. Anel, P. de Paz, Sperm subpopulations in Iberian red deer epididymal sperm and their changes through the cryopreservation process, Biol Reprod 72 (2005) 316-327.

[20] L. Anel, M. Alvarez, E. Anel, F. Martinez-Pastor, F. Martinez, C. Chamorro, et al., Evaluation of three different extenders for use in emergency salvaging of epididymal spermatozoa from a Cantabric brown bear, Reprod Domest Anim 46 (2011) e85-90, https://doi.org/10.1111/j.1439-0531.2010.01646.x.

[21] J. Tamayo-Canul, M. Alvarez, M. Mata-Campuzano, M. Alvarez-Rodríguez, P. de Paz, L. Anel, et al., Effect of storage method and extender osmolality in the quality of cryopreserved epididymal ram spermatozoa, Anim Reprod Sci 129 (2011) 188-199, https://doi.org/10.1016/j.anireprosci.2011.11.003.

[22] A.F. Martínez, F. Martínez-Pastor, M. Alvarez, M.R. Fernández-Santos, M.C. Esteso, P. de Paz, et al., Sperm parameters on Iberian red deer: electroejaculation 
and post-mortem collection, Theriogenology 70 (2008) 216-226, https://oi.org/ 10.1016/j.theriogenology.2008.04.001

[23] J. López-Saucedo, J. Santiago-Moreno, R. Fierro, D. Izquierdo, M.A. Coloma, M.G. Catalá, et al., Fertilization capacity of cryopreserved Iberian ibex epididymal sperm in a heterologous in vitro fertilization assay, Zygote Camb Engl 23 (2015) 136-144, https://doi.org/10.1017/S0967199413000518.

[24] S. Blash, D. Melican, W. Gavin, Cryopreservation of epididymal sperm obtained at necropsy from goats, Theriogenology 54 (2000) 899-905, https://doi.org/10. 1016/S0093-691X(00)00400-3.

[25] M.R. Fernández-Santos, M.C. Esteso, V. Montoro, A.J. Soler, J.J. Garde, Cryopreservation of Iberian red deer (Cervus elaphus hispanicus) epididymal sperma- tozoa: effects of egg yolk, glycerol and cooling rate, Theriogenology 66 (2006) 1931-1942, https://doi.org/10.1016/j.theriogenology.2006.05.012.

[26] M.R. Fernández-Santos, A.J. Soler, M. Ramón, J.L. Ros-Santaella, A. Maroto-Morales, O. García-Álvarez, et al., Effect of post-mortem time on post-thaw characteristics of Spanish ibex (Capra pyrenaica) spermatozoa, Anim Reprod Sci 129 (2011) 56-66, https://doi.org/10.1016/j.anireprosci.2011.09.011.

[27] J. Santiago-Moreno, A. Toledano-Díaz, A. Pulido-Pastor, J. Dorado, A.

Gómez-Brunet, A. López-Sebastián, Effect of egg yolk concentration on cryopreserving Spanish ibex (Capra pyrenaica) epididymal spermatozoa, Theriogenology 66 (2006) 1219-1226, https://doi.org/10.1016/j.theriogenology.2006.03.031. 